\title{
The Effect of Modified Atmosphere Storage on the Quality of Fresh Dill (Anethum graveolens L.)
}

D. Tsamaidi and H.C. Passam

Agricultural University of Athens, Laboratory of Vegetable Production, Iera Odos 75, 11855 Athens, Greece

Keywords: chlorophyll, temperature, total phenolics, vitamin C, oxygen, carbon dioxide

\begin{abstract}
Because of its high perishability, fresh dill (Anethum graveolens L.) cannot be stored for more than a few days, even at low temperature. The present study was therefore undertaken to determine whether modified atmospheres based on changes in $\mathrm{CO}_{2}$ and $\mathrm{O}_{2}$ concentrations would benefit dill storage. Dill cv. Ducat was cultivated between October 2009 and January 2010. Plants were harvested at the fresh market stage (before flowering) and randomly selected leaves were weighed, placed in airtight plastic bags and stored for 10 days at $5^{\circ} \mathrm{C}$. The atmospheres within the containers $\left(\mathrm{O}_{2}-\mathrm{CO}_{2}-\mathrm{N}_{2}\right)$ were initially as follows: (1) 20-0-80 (air), (2) 20-10-70, (3) 10-0-90, and (4): 10-10-80. The changes in $\mathrm{O}_{2}-\mathrm{CO}_{2}$ concentrations were monitored during storage; fresh weight, chlorophyll, vitamin $\mathrm{C}$ and total phenolics concentrations were measured before and after storage. The oxygen concentration within the bags during storage fell to $12.5 \%$ (treatment 1 ) and $17.9 \%$ (treatment 2) indicating a reduction of respiration due to the inclusion of $10 \% \mathrm{CO}_{2}$ within the initial atmosphere $\left(20 \% \mathrm{O}_{2}\right)$. At an initial concentration of $10 \% \mathrm{O}_{2}$, the oxygen level decreased to $5.5 \%$ and $5.8 \%$ in the absence or presence of $10 \% \mathrm{CO}_{2}$ (treatments 3 and 4), respectively. In each case, the decrease in $\mathrm{O}_{2}$ was accompanied by a corresponding increase in $\mathrm{CO}_{2}$ concentration. Weight loss during storage ranged from 2.6-5.3\% and the total phenolics levels decreased in all treatments except treatment 3 (10-0-90). Vitamin $C$ and chlorophyll concentrations decreased during storage. Vitamin $C$ loss was similar in all treatments, but chlorophyll loss was significantly higher in the treatments with $10 \% \mathrm{CO}_{2}$. In consequence, although modified atmospheres containing $10 \% \mathrm{CO}_{2}$ reduce respiratory activity they are of questionable value for dill because the decrease in chlorophyll concentration causes a decrease in quality.
\end{abstract}

\section{INTRODUCTION}

The shelf-life of fresh vegetable produce is limited by physiological ageing and water loss (O'Beirne, 1990). Water loss leads to weight loss and shriveling whereas physiological ageing (senescence) occurs when the starch/sugar stored within the product is consumed during respiration; therefore shelf-life is inversely proportional to respiration rate (Day 1990). Modified Atmosphere Packaging (MAP) addresses both these factors and enables significant product-specific shelf-life extension (Wills et al., 1989; Church, 1995). Under conditions of MAP the $\mathrm{O}_{2}$ tension within the storage atmosphere falls, thus reducing the rate of respiration. However, the $\mathrm{O}_{2}$ level must not decrease below the point at which anaerobic respiration occurs.

The MAP procedure most often used for fresh fruit and vegetables is to enclose a small amount of produce in a film package and periodically monitor the resulting 
atmosphere and product quality (Salveit, 2003). For example, 22 species of fresh herbs are exported from Israel to Europe, mainly during winter, packed in cartons and transported by air (Aharoni et al., 1989). When these herbs are subsequently exposed to warm air during marketing, they are vulnerable to yellowing and decay. Packaging in cartons with non-sealed NP-PE liners was found to delay leaf senescence (Hruschka and Wang, 1979) possibly due to the elevation of $\mathrm{CO}_{2}$ concentration within the PE liners (Aharoni et al., 1988).

Apart from low temperatures, modified atmospheres are the most effective method to retard senescence of harvested leafy vegetables (Lipton, 1975). Chlorophyll loss is delayed equally well by low $\mathrm{O}_{2}(<5 \%)$ and by elevated $\mathrm{CO}_{2}(>5 \%)$. The combination of these two gases is slightly more effective than either one alone (Lipton and Mackey, 1987). However, the creation of modified atmospheres by film packaging can be harmful if the temperature is not carefully controlled during storage. Fluctuations in temperature will affect the respiration rate amd may lead to an improper balance between $\mathrm{CO}_{2}$ and $\mathrm{O}_{2}$, resulting in anaerobiosis (Hardenburg, 1971).

The objective of this experiment was to determine the effect of low $\mathrm{O}_{2}$ and high $\mathrm{CO}_{2}$ on the storage behavior and quality characteristics of dill.

\section{MATERIALS AND METHODS}

The experiment was carried out at the Agricultural University of Athens. Seeds of dill (Anethum graveolens L. cv. Ducat) were sown in trays containing a commercial peat compost (Klasmann TS-2, Klasmann-Deilmann GmbH, Geeste, Germany) in October 2009 and placed in an unheated greenhouse. At the stage of 3-4 true leaves (30 days after sowing) the plants were transplanted to $11 \mathrm{~L}$ pots containing a $(1: 1 \mathrm{v} / \mathrm{v})$ mixture of peat and perlite (Perloflor P4, Perlite Hellas, Piraeus, Greece) enriched with 150g potassium monophosphate, $40 \mathrm{~g}$ potassium sulphate, $20 \mathrm{~g}$ magnesium sulphate, $10 \mathrm{~g}$ trace elements (Nutrileaf) and $300 \mathrm{~g}$ marble dust per $\mathrm{m}^{3}$. Each pot contained four plants. The pots were spaced at $50 \times 50 \mathrm{~cm}$ in an unheated, glass-covered greenhouse. During cultivation plants were fertilized with 300 ppm N twice a week. Plants were harvested in January 2010, just prior to flowering. At harvest, plants were cut $1 \mathrm{~cm}$ above the soil and any old, senesced leaves removed.

Immediately after harvest, leaves were weighed and the percent dry matter content determined by drying at $72^{\circ} \mathrm{C}$ for 3 days. Randomly selected leaves were placed in sealed, airtight polyethylene food-bags, and stored for 10 days at $5^{\circ} \mathrm{C}$. Each bag (with volume $600 \mathrm{ml}$ ) contained 3 leaves (together with their petioles), weighing $15 \mathrm{~g}$. The atmospheres within the bags $\left(\mathrm{O}_{2}-\mathrm{CO}_{2}-\mathrm{N}_{2}\right)$ were initially as follows: (1) 20-0-80 (air), (2) 20-10-70, (3) 10-0-90, and (4): 10-10-80. Changes in $\mathrm{O}_{2}$ and $\mathrm{CO}_{2}$ concentrations were monitored after storage. At the end of storage, leaves were weighed to determine weight loss and then dried at $72^{\circ} \mathrm{C}$ for 3 days for the determination of dry matter. Quality characteristics were monitored before and after storage. Chlorophyll a, chlorophyll $\mathrm{b}$ and total chlorophyll concentration were measured using the method of Arnon (1949), vitamin C (L-ascorbic acid) was measured according to Bajaj and Kaur (1981), while total phenolics were measured by the method of Lisiewska et al. (2006).

The results were subjected to analysis of variance (ANOVA) and means compared by the application of Duncan's multiple range test using the statistical package Statgraphics plus 5.1. 


\section{RESULTS}

Weight loss during storage ranged from $2.6-5.3 \%$ and was significantly lower in treatment $1(20 / 0 / 80)$ than the other treatments (Table 1). The oxygen concentration within the bags during storage fell to $12.5 \%$ (treatment 1) and $17.9 \%$ (treatment 2) indicating a reduction in respiration rate due to the inclusion of $10 \% \mathrm{CO}_{2}$ within the initial atmosphere $\left(20 \% \mathrm{O}_{2}\right)$. With an initial concentration of $10 \% \mathrm{O}_{2}$, the oxygen level decreased to $5.5-5.8 \%$ in the absence or presence of $10 \% \mathrm{CO}_{2}$ indicating no effect of $\mathrm{CO}_{2}$ on respiration rate at a low $\mathrm{O}_{2}$ tension (Table 2). In treatments with reduced $\mathrm{O}_{2}(10 \%)$ the concentration of $\mathrm{CO}_{2}$ within the bags at the end of storage was lower than in the corresponding treatments with $20 \% \mathrm{O}_{2}$ (Table 2).

The concentration of vitamin $\mathrm{C}$ decreased during storage and after 10 days was significantly lower in the treatment with $10 \% \mathrm{O}_{2}$ and $10 \% \mathrm{CO}_{2}$ (Table 3). Total phenolics levels tended to decrease during storage but not to a statistically significant level (Table 3 ). However, the concentration of chlorophyll ( $\mathrm{a}, \mathrm{b}$ and total) decreased significantly during storage only in treatments with $10 \% \mathrm{CO}_{2}$ (Table 4).

\section{DISCUSSION}

Recommended for modified atmospheres for the storage of the herbs chervil, chives, coriander, dill, sorrel and watercress are 5-10\% $\mathrm{O}_{2}$ and $4 \% \mathrm{CO}_{2}$ at a temperature range of $0-5^{\circ} \mathrm{C}$, with optimum $1^{\circ} \mathrm{C}$ (Salveit, 2003).

Aharoni et al. (1989) found that packaging in a sealed PE (S.P.E.) lined carton resulted in the maximal reduction of both yellowing and decay. Measuring the changes of respiratory gases inside the packages of chives revealed that the accumulation of $\mathrm{CO}_{2}$ $(5.7 \%)$ rather than the decrease in $\mathrm{O}_{2}(12 \%)$ was the reason for retardation of senescence. In order to efficiently retard the yellowing of watercress without the development of offodors during storage, the $\mathrm{CO}_{2}$ level should be above $7 \%$ and the $\mathrm{O}_{2}$ level should not drop below 5\%. In both dill and chives $5 \% \mathrm{CO}_{2}$ markedly retarded chlorophyll loss.

Positive effects of increased $\mathrm{CO}_{2}$ concentration on the maintenance of vitamin $\mathrm{C}$ is known in leafy vegetables (Sousan and Abd el-Aal 2007), while the opposite effect has been observed for phenolics (Oboh, 2005). Ishi and Okubo (1984) found that an increase in $\mathrm{CO}_{2}$ concentration leads to a reduction in respiration, as well as better maintenance of the concentration of chlorophyll and vitamin C. For cardamom (Aharoni et al., 1989) and parsley (Saltveit, 1989), the best storage conditions are $0-2^{\circ} \mathrm{C}$ with a $\mathrm{CO}_{2}$ concentration of $10 \%$. Elevated levels of $\mathrm{CO}_{2}$ slow down the loss of chlorophyll and the degradation of green colour of plant leaves due to the reduction of respiration (Kader, 1986).

In conclusion, the respiratory activity of dill foliage is reduced by MAP containing $10 \% \mathrm{O}_{2}$ (with or without $\mathrm{CO}_{2}$ ) or $20 \% \mathrm{O}_{2}+10 \% \mathrm{CO}_{2}$, as indicated by the relative changes of $\mathrm{O}_{2}$ and $\mathrm{CO}_{2}$ concentrations within the bags. Since, however, the presence of $\mathrm{CO}_{2}(10 \%)$ causes a decrease in chlorophyll and vitamin $\mathrm{C}$ concentration, which means a reduction in quality, it is clearly preferable to reduce the $\mathrm{O}_{2}$ concentration, rather than increase $\mathrm{CO}_{2}$, during MAP storage of dill.

\section{ACKNOWLEDGEMENTS}

This research has been co-financed by the European Union (European Social Fund - ESF) and Greek national funds through the Operational Program "Education and Lifelong Learning" of the National Strategic Reference Framework (NSRF) - Research Funding Program: Heracleitus II. Investing in knowledge society through the European Social Fund. 


\section{Literature Cited}

Aharoni, N., Dvir, O., Chalupowis, D., Zhalupowisz, Z. and Aharon, Z. 1993. Coping with postharvest physiology of fresh culinary herbs. Acta Hort. 344: 69-78.

Aharoni, N,. Dvir, O., Reuveni, A., Aharon, Z., Gur, G., Noi, M., Tene, A., Kuris, U. and Efrat, U. 1988. Film packaging and vacuum precooling of green herbs for export. Hassadeh 68: 767-771 (Hebrew, with English summary).

Aharoni, N., Reuveni, A. and Dvir, O. 1989. Modified atmospheres in film packages delay senescence and decay of fresh herbs. Acta Hort. 88: 255-262.

Arnon, D.I. 1949. Copper enzyme in isolated chloroplast polyphenoloxidase in Beta vulgaris. Plant Physiol. 24: 1-15.

Bajaj, K.L. and Kaur, G. 1981. Spectrophotometric determination of 1-ascorbic acid in vegetables and fruits. The Analyst. 106 (1): 117-120.

Church, I.J., and Parsons, A.L. 1995. Modified Atmosphere Packaging technology: a review. J. Sci. Food Agric. 67: 143-152.

Day, B. 1990. Modified atmosphere packaging of selected prepared fruit and vegetables. pp. 230-233. In: Zeuthen P, Cheftel J C, Eriksson C, Gormley T R P. Linko P \& Paulus K. (eds), Elsevier, Processing and Quality of Foods. Vol 3: Chilled Foods: The Revolution in Freshness. London, UK.

Hardenburg, R.E. 1971. Effect of in package environment on keeping quality of fruits and vegetables. Hort. Science 6: 198-201.

Hruschka, H.W., and Wang, C.Y. 1979. Storage and shelf life of packaged watercress, parsley and mint. USDA, Mktg. Res. Rep. 1102.

Ishi, K. and Okubo, M. 1984. The keeping quality of Chinese chive (Allium tuberosum Rottler) by low temperature and seal-packaging with polyethylene bag. J. Jap. Soc. Hort. Sci. 53 (1): 87-95.

Kader, A.A. 1986. Biochemical and physiological basis for effects of controlled and modified atmospheres on fruit and vegetables. Food Tech. 40: 99-100.

Lisiewska, Z., Kmiecik, W. and Korus, A. 2006. Content of vitamin C, carotenoids, chlorophylls and polyphenols in green parts of dill (Anethum graveolens L.) depending on plant height. J. Food Comp. Anal. 19: 134-140.

Lipton, W.J. 1975. Controlled atmospheres for fresh vegetables and fruits - why and when? In: Haard, N.F., and Salunke, D.K. (eds) Postharvest Biology and Handling of Fruits and Vegetables. AVI. Publ. Co., Westport, CT. 130-143.

Lipton, W.J., and Mackey, B.E. 1987. Physiological and quality responses of Brussels sprouts to storage in controlled atmospheres. J. Amer. Soc. Hort. Sci. 112: 491-496.

O'Beirne, D. 1990. Modified atmosphere packaging of fruits and vegetables. Chilled foods: The revolution in freshness. Elsevier Applied Science. Publ.. 183-199.

Oboh, G., 2005. Effect of blanching on the antioxidant property of some tropical green leafy vegetables. Food Sci. Tech. 38: 513-517

Saltveit, M.E. Jr. 1989. A summary of requirements and recommendations for the controlled and modified atmosphere storage of harvested vegetables. In: Proc. 5th Int. Controlled Atmosphere Research Conf. Wenatchee, Wash. USA. 14-16 June. 2: 332.

Salveit, M.E. 2003. A summary of CA requirements and recommendations for vegetables. Acta Hort. 600: 723-727.

Sousan, S.L. and Abd El-Aal, H.A. 2007. Minerals profile- shelf life extension and nutritive value of fresh green leafy vegetables consumed in Egypt. In: Africans Crop Science Conference Proceedings. 8: 1817-1826. 
Wills, R.B.H., Mc Glasson, W.B., Graham, D., Lee, T.H., Hall, E.G. 1989. Postharvest. An Introduction to the Physiology and Handling of Fruits and Vegetables. BSP Professional Books. Oxford UK.

\section{Tables}

Table 1. The effect of modified atmospheres on the weight loss (\%) of foliage biomass after 10 days storage of dill leaves.

\begin{tabular}{cc}
\hline Modified Atmosphere & Weight loss of foliage biomass (\%) \\
\hline A1 (20.0.80) & $2.63 \mathrm{~b}$ \\
A2 (20.10.70) & $5.30 \mathrm{a}$ \\
A3 (10.0.90) & $4.72 \mathrm{a}$ \\
A4 (10.10.80) & $4.57 \mathrm{a}$ \\
\hline
\end{tabular}

Means followed by the same letter are not significantly different at $\mathrm{P}=0.05$.

Table 2. The effect of modified atmospheres on the final concentration $\mathrm{O}_{2}(\%)$ and $\mathrm{CO}_{2}$ (\%) after 10 days storage of dill leaves.

\begin{tabular}{ccc}
\hline Modified & \% $\mathbf{O}_{2}$ & \% $_{\mathbf{C O}}$ \\
\hline Atmosphere & $12.50 \mathrm{~b}$ & $7.75 \mathrm{c}$ \\
$\mathbf{A} 1 \mathbf{( 2 0 . 0 . 8 0 )}$ & $17.93 \mathrm{a}$ & $15.58 \mathrm{a}$ \\
$\mathbf{A 2}(\mathbf{2 0 . 1 0 . 7 0 )}$ & $5.81 \mathrm{c}$ & $3.79 \mathrm{~d}$ \\
$\mathbf{A 3}(\mathbf{1 0 . 0 . 9 0 )}$ & $5.49 \mathrm{c}$ & $13.82 \mathrm{~b}$ \\
\hline $\mathbf{A 4}(\mathbf{1 0 . 1 0 . 8 0 )}$ & &
\end{tabular}

Means followed by the same letter are not significantly different at $\mathrm{P}=0.05$.

Table 3 The effect of modified atmospheres on the concentration of vitamin $\mathrm{C}(\mathrm{mg} / 100 \mathrm{~g}$ fresh matter) and total phenolics (mg GAE/100g fresh matter) of dill leaves.

\begin{tabular}{|c|c|c|c|}
\hline $\begin{array}{c}\text { Modified } \\
\text { Atmospheres } \\
\end{array}$ & $\begin{array}{c}\text { Vitamin } C \\
\text { (mg / 100g f.w.) } \\
\end{array}$ & \multicolumn{2}{|c|}{$\begin{array}{c}\text { Total phenolics } \\
\text { (mg GAE/100g f.w.) }\end{array}$} \\
\hline A0 (Fresh) & $511.77 \mathrm{a}$ & \multicolumn{2}{|r|}{273.90} \\
\hline A1 (20.0.80) & $253.57 \mathrm{~b}$ & \multicolumn{2}{|r|}{255.62} \\
\hline A2 (20.10.70) & $224.37 \mathrm{bc}$ & \multicolumn{2}{|r|}{255.34} \\
\hline A3 (10.0.90) & $254.20 \mathrm{~b}$ & \multicolumn{2}{|r|}{271.05} \\
\hline A4 (10.10.80) & $219.08 \mathrm{c}$ & \multicolumn{2}{|r|}{263.55} \\
\hline \multicolumn{4}{|c|}{$\begin{array}{l}\text { Table 4. The effect of modified atmospheres on the concentration of chlorophyll a } \\
\text { chlorophyll } \mathrm{b} \text { and total chlorophyll }(\mathrm{mg} / 100 \mathrm{~g} \text { fresh matter) of dill leaves. }\end{array}$} \\
\hline \multirow[t]{2}{*}{ Modified Atmospheres } & Chlorophyll a & Chlorophyll b & Total Chlorophyll \\
\hline & \multicolumn{3}{|c|}{ mg / 100 g f.w. } \\
\hline A0 (Fresh) & $94.83 \mathrm{a}$ & $38.74 \mathrm{a}$ & $133.57 \mathrm{a}$ \\
\hline A1 (20.0.80) & $85.70 \mathrm{a}$ & $40.50 \mathrm{a}$ & $126.20 \mathrm{a}$ \\
\hline A2 (20.10.70) & $52.35 \mathrm{~b}$ & $21.90 \mathrm{~b}$ & $74.25 \mathrm{~b}$ \\
\hline A3 (10.0.90) & $90.77 \mathrm{a}$ & $34.45 \mathrm{a}$ & $115.76 \mathrm{a}$ \\
\hline A4 (10.10.80) & $41.62 \mathrm{~b}$ & $16.65 \mathrm{~b}$ & $58.27 \mathrm{~b}$ \\
\hline
\end{tabular}


